\title{
Leaf anatomy as an additional taxonomy tool for 16 species of Malpighiaceae found in the Cerrado area (Brazil)
}

\author{
Josiane Silva Araújo • Aristéa Alves Azevedo • \\ Luzimar Campos Silva - Renata Maria Strozi Alves Meira
}

Received: 17 October 2008/Accepted: 24 January 2010/Published online: 14 April 2010

(C) Springer-Verlag 2010

\begin{abstract}
This work describes the leaf anatomy of 16 species belonging to three genera of the Malpighiaceae family found in the Cerrado (Minas Gerais State, Brazil). The scope of this study was to support the generic delimitation by contributing to the identification of the species and constructing a dichotomous identification key that includes anatomical characters. The taxonomic characters that were considered to be the most important and used in the identification key for the studied Malpighiaceae species were as follows: the presence and location of glands; presence of phloem in the medullary region of the midrib; mesophyll type; presence and type of trichomes; and presence, quantity, and disposition of accessory bundles in the petiole. It was also possible to indicate promising characters for future taxonomic and phylogenetic studies in the Malpighiaceae family, especially for the Banisteriopsis, Byrsonima, and Heteropterys genera.
\end{abstract}

Keywords Taxonomy $\cdot$ Byrsonima $\cdot$ Banisteriopsis . Heteropterys $\cdot$ Cerrado

\section{Introduction}

The Malpighiaceae family has nearly 65 genera and 1,250 species occurring in tropical and subtropical areas in both hemispheres (Anderson 2001). Although this family is clearly monophyletic (Davis et al. 2001), the infrafamily

J. S. Araújo · A. A. Azevedo · L. C. Silva

R. M. S. A. Meira ( $\square)$

Departamento de Biologia Vegetal, Universidade Federal de

Viçosa (UFV), Av. P. H. Rolfs, s/n, Campus Universitário,

Viçosa, MG 36570-000, Brazil

e-mail: rmeira@ufv.br classification based on winged or unwinged fruit is artificial (Anderson 1978). It is difficult to study this family primarily because of its large number of species, nomenclatural problems, and difficulties in identification by taxonomists. For example, glandular calyces are common among the neotropical Malpighiaceae, but it is possible to find eglandular calyces in species within the genera Banisteriopsis, Byrsonima, Galphimia, and Pterandra (Anderson 1990), making it difficult to distinguish these genera by using this morphological character. Such issues arise, in particular, because of the morphological variability and species synonymies (Gates 1982; MakinoWatanabe et al. 1993; Anderson 2001).

The floral architecture of all species in Malpighiaceae is very similar; therefore, characters such as leaf shape, length, width, and leaf pubescence as well as the extremely diverse fruit types are commonly used to sort out species within several genera (Anderson 1979; Mamede 1981; Davis et al. 2001). The phylogeny of Malpighiaceae is based on molecular analyses, which include fruit morphology, pollen grain morphology chromosome number, and distribution of species (Davis et al. 2001; Cameron et al. 2001); however we could not find evaluations that included anatomical characters.

Although the leaf is the organ that anatomically varies the most based on the hierarchic level (species, genus, or even the family) and despite the influence of environmental factors, many anatomical characters are useful for systematics, particularly the leaf epidermis (Metcalfe and Chalk 1979; Dickison 2000). Therefore, since the 19th century, taxonomists have investigated anatomical characters that may support species identification (Solereder 1908; Metcalfe and Chalk 1950, 1979).

Among the most recent works on anatomy applied to taxonomy, the research carried out on species belonging to 
the Brazilian flora stand out the most (Gomes et al. 2005; Rio et al. 2005; Fonsêca et al. 2007). Research on the anatomy of Malpighiaceae has been carried out on a few species without emphasis on the taxonomy (Arambarri et al. 2006; Ferreira 1981; Gavilanes and Ferreira 19741976; Guimaraes et al. 1985). However, in terms of anatomy as it applies to taxonomy, few references were found for this family (Mamede 1993; Attala 1997), which reveals how scarce these studies are.

It is important to highlight that the use of anatomical characters as a source of information for systematics necessitates an understanding of the character variation that a single individual can represent among the specimens of a particular species, group, or related taxa. The structural variation may be documented quantitatively or qualitatively (Dickison 2000). Thus, it is necessary to evaluate a higher number of specimens and, if possible, include specimens from collections in different locations.

In the Brazilian Cerrado, the Malpighiaceae stand out both in the number of woody species (Ratter et al. 1997) and other phytosociological parameters such as density, frequency, and absolute and relative dominance (Saporetti et al. 2003; Borges and Shepherd 2005). The importance of Banisteriopsis, Byrsonima, and Heteropterys must be emphasized since these genera have a high number of species that are difficult to identify when they are not fertile. In a recent review, 10 species of Byrsonima, 30 of Banisteriopsis, and 12 of Heteropterys were listed in the Cerrado vegetation (Mendonça et al. 2008). Therefore, anatomical characteristics from vegetative organs are useful to distinguish species.

This work describes the leaf anatomy of 16 species belonging to three genera of the Malpighiaceae family found in the Cerrado (Minas Gerais State, Brazil). The scope of this study is to improve the generic delimitation by contributing to the identification of species and constructing a dichotomous identification key that includes anatomical characters.

\section{Materials and methods}

Leaves of all Malpighiaceae species collected in Paraopeba National Reserve (FLONA; $19^{\circ} 16^{\prime} \mathrm{S}$ and $44^{\circ} 23^{\prime} \mathrm{W}$; Minas Gerais State) were analyzed. This is a conservation unit managed by IBAMA (Brazilian Institute of Environment and Renewable Natural Resources) that has nearly 200 ha, of which 150 ha are the Cerrado (Neri et al. 2005).

The samples were kept in the herbarium at the Federal University of Viçosa (VIC), Minas Gerais, and included 16 species belonging to three genera: Banisteriopsis (seven species), Byrsonima (five species), and Heteropterys (four species). Samplings of the same species from voucher material kept in the Herbaria of the University of Brasilia (UB), University of São Paulo (SPF), and Rio de Janeiro Botanical Garden (RB) were also taken and used as replications (Table 1).

The criteria used for selecting the leaves were as follows: (1) herborized material quality, (2) fully expanded leaves, and (3) identification by experts in the Malpighiaceae family.

Leaves were boiled in distilled water until their submersion, treated with $2 \%$ potassium hydroxide for $2 \mathrm{~h}$ at room temperature (Smith and Smith 1942), dehydrated in ethylic series, and then stored in $70 \%$ ethanol.

The leaf blade (including basal, middle, and distal parts) and petiole were hand sectioned. Cross and longitudinal sections were cleared by means of a $50 \%$ sodium hypochlorite and stained with basic fuchsin-Astra blue. Slides were mounted in glycerogelatin and sealed with transparent nail polish (Kraus and Arduin 1997).

To analyze the venation pattern and stomata type, samplings of $20 \mathrm{~mm}^{2}$ were subjected to diaphanization and staining with alcoholic safranin (Shobe and Lersten 1967). Slides were then mounted with synthetic resin (Permount SP15-500, Fisher Scientific, NJ, USA).

The analysis and photographic records were performed under a photomicroscope (Olympus AX70TRF, Olympus Optical, Tokyo, Japan) with attached image capture. The material was also recorded by means of hand drawings made with the aid of a camera lucida attached to a light microscope (Olympus CBA, Olympus Optical, Tokyo, Japan).

All 16 Malpighiaceae species were compared according to their analyzed structural characteristics by using a presence/absence matrix (Table 2). This matrix used Sorensen's index and an average group linkage technique (also known as unweighted pair-group method using arithmetic averages, UPGMA) with the MVSP $3.13 \mathrm{~m}$ program (Mueller-Dombois and Ellenberg 1974). Also, principal component analysis (PCA) was calculated by using the same matrix and performed using NTSys software (Rohlf 1988; Sokal and Rohlf 1995).

The vascular bundle arrangement in the petiole was classified according to Howard (1979). Venation pattern and stomata type of the leaf blade are classified according to Metcalfe and Chalk classification (1979). Trichomes were analyzed according to the classification proposed by Theobald et al. (1979).

\section{Results}

Anatomic description

The petiole outlines of Banisteriopsis anisandra (Fig. 1) and B. pubipetala are concave-convex in cross-section. 
Table 1 List of the voucher material species. Information about the vegetation is included when it was described on the voucher material label

\begin{tabular}{|c|c|c|c|c|}
\hline \multirow[t]{2}{*}{ Species } & \multicolumn{4}{|l|}{ Herbaria } \\
\hline & $\begin{array}{l}\text { Federal University } \\
\text { of Viçosa }\end{array}$ & $\begin{array}{l}\text { University } \\
\text { of Sao Paulo }\end{array}$ & $\begin{array}{l}\text { University } \\
\text { of Brasilia }\end{array}$ & $\begin{array}{l}\text { Rio de Janeiro } \\
\text { Botanic Garden }\end{array}$ \\
\hline Banisteriopsis anisandra (Juss.) B. Gates & VIC 9726 Cerrado & $\begin{array}{l}\text { SPF } 35657 \text { - Rocky } \\
\text { Outcrop/MG }\end{array}$ & & RB 227241 \\
\hline B. argyrophylla (Juss.) B. Gates & $\begin{array}{l}\text { VIC 10014, VIC } 10251 \\
\text { Cerrado }\end{array}$ & $\begin{array}{l}\text { SPF } 15643 \text { Porto } \\
\text { Ferreira/SP }\end{array}$ & $\begin{array}{l}\text { UB } 3547 \text { Perto Córrego } \\
\text { Terra Branca/DF }\end{array}$ & \\
\hline B. campestris (Juss.) Little & VIC 9934 Cerrado & & $\begin{array}{l}\text { UB } 6738 \text { Chapada dos } \\
\text { Veadeiros/GO, UB } 7980 \\
\text { Serra dos Cristais/GO }\end{array}$ & \\
\hline $\begin{array}{l}\text { B. gardneriana (A. Juss.) W. R. } \\
\text { Anderson and B. Gates }\end{array}$ & VIC 9140 Cerrado & $\begin{array}{l}\text { SPF } 44593 \text { Vale do Rio } \\
\text { Itacambiruçu/MG }\end{array}$ & $\begin{array}{l}\text { UB } 34517 \text { Serra dos } \\
\text { Pireneus/GO }\end{array}$ & \\
\hline B. laevifolia (Juss.) B. Gates & VIC 9931 Cerrado & SPF 48780 & $\begin{array}{l}\text { UB } 31733 \text { Serra Geral do } \\
\text { Paraná/GO }\end{array}$ & \\
\hline B. malifolia (Nees \& Mart.) B. Gates & $\begin{array}{l}\text { VIC } 9982 \text { Jaboticatubas, } \\
\text { São José da Serra, Cipó } \\
\text { Camping Club/MG }\end{array}$ & & $\begin{array}{l}\text { UB } 13369 \text { Cristalina/GO, } \\
\text { UB } 11588 \text { Diamantina/ } \\
\text { MG }\end{array}$ & \\
\hline B. pubipetala (A. Juss.) Cuatrec. & VIC 10244 Cerrado & $\begin{array}{l}\text { SPF } 18052 \\
\text { Andaraí/BA }\end{array}$ & UB 34795 Estado de Goiás & \\
\hline Byrsonima basiloba A. Juss & VIC 9963 Cerrado & & $\begin{array}{l}\text { UB } 24112 \text { Chapada dos } \\
\text { Veadeiros/GO, UB } 7545 \\
\text { Serra Geral do Paraná/GO }\end{array}$ & \\
\hline B. coccolobifolia (Spreng.) Kunth & $\begin{array}{l}\text { VIC } 9833 \text {, VIC 25995, VIC } \\
9131 \text { Cerrado }\end{array}$ & & & \\
\hline B. crassifolia (L.) Kunth & $\begin{array}{l}\text { VIC 9152, VIC } 9153 \\
\text { Cerrado }\end{array}$ & & & RB 211132 \\
\hline B. lancifolia A. Juss. & VIC 9753 Cerrado & $\begin{array}{l}\text { SPF } 170071 \text { Alto } \\
\text { Paraíso }\end{array}$ & $\begin{array}{l}\text { UB } 6343 \text { Chapada dos } \\
\text { Veadeiros/GO }\end{array}$ & \\
\hline B. verbascifolia Rich. ex A. Juss. & $\begin{array}{l}\text { VIC 9731, VIC 9157, VIC } \\
\text { 9158, VIC } 9159 \text { Cerrado }\end{array}$ & & & \\
\hline Heteropterys anoptera A. Juss. & VIC 9734 Cerrado & & $\begin{array}{l}\text { UB } 7359 \text { Chapada dos } \\
\text { Veadeiros/GO, UB 23771 } \\
\text { Serra do Espinhaço/MG }\end{array}$ & \\
\hline H. byrsonimifolia A. Juss. & $\begin{array}{l}\text { VIC } 8943 \text {, VIC } 9763 \text { Serra } \\
\text { do Cipó/MG, VIC } 24126 \\
\text { Cerrado Stricto Sensu - } \\
\text { Parque Estadual do } \\
\text { Lajeado - Palmas/TO }\end{array}$ & & & \\
\hline H. campestris A. Juss. & $\begin{array}{l}\text { VIC } 10015, \text { VIC } 25775 / \text {, } \\
\text { VIC } 25653 \text { Cerrado }\end{array}$ & & & \\
\hline H. tomentosa A. Juss. & VIC 10318 Cerrado & & $\begin{array}{l}\text { UB } 17164 \text { Serra de } \\
\text { Xavantina/MT, UB } 39721 \\
\text { Xavantina/MT }\end{array}$ & \\
\hline
\end{tabular}

Banisteriopsis argyrophylla, B. campestris (Fig. 2), B. gardneriana (Fig. 3), B. laevifolia, B. malifolia, and all species of Byrsonima (Fig. 4-6) and Heteropterys (Fig. 7 and 8 ) have a plan-convex petiole outline. The surface is slightly sinuous in B. gardneriana (Fig. 3), B. malifolia, and all species of Byrsonima (except in B. crassifolia) as well as Heteropterys byrsonimifolia (Fig. 7) and H. tomentosa (Fig. 8).
Three types of petiole vascular patterns are identified. In Banisteriopsis gardneriana (Fig. 3), Byrsonima basiloba (Fig. 4), B. coccolobifolia, B. lancifolia (Fig. 5), and in all species of Heteropterys (Fig. 7 and 8), an arc invaginating at the ends is found. A curved arc is observed in Banisteriopsis anisandra (Fig. 1), B. argyrophylla, B. campestris (Fig. 2), B. pubipetala, B. laevifolia, and B. malifolia. A pattern constituted by free bundles forming an arc with 
Table 2 Presence (1) and absence (0) matrix of 16 Malpighiaceae species found in the FLONA of Paraopeba, Minas Gerais, Brazil

Analyzed characteristics

BaA BaAR BaC BaG BaL BaM BaP ByB ByCO ByCR ByLA ByV HA HB HC HT

Single-layered epidermis on both sides (1) $00 \quad 1$

Bilayered epidermis on some regions of 10 the adaxial side (2)

Guard cells forming ledge only on the $\begin{array}{llllllllllllllllllllllll}0 & 0 & 0 & 0 & 0 & 0 & 0 & 1 & 1 & 1 & 1 & 1 & 0 & 0 & 0 & 0\end{array}$ outer side (3)

Subsidiary cells projected over the guard cells (4)

One pair of leaf glands (5)

Glands present at the petiole base (6) 110

Glands present in the lower part of the leaf $0 \quad 0$ (7)

Glands present in the middle part of the leaf (8)

V-shaped nonglandular trichomes $(9)$

Y-shaped nonglandular trichomes (10)

T-shaped nonglandular trichomes (11)

Isobifacial leaves (12)

Dorsiventral leaves (13)

Vascular bundles arranged in open arc (14)

Vascular bundles arranged in closed arc with phloem in the midrib (15)

Vascular bundles arranged in closed arc without phloem in the medullary region of the midrib (16) convex shape (17)

Petiole on cross-section with plan-convex 0 shape (18)

Petiolar vascular system arranged as a curved arc (19)

Petiolar vascular system arranged in an arc 0 and invaginate at ends (20)

Petiolar vascular system comprised of free $0 \quad 0$ bundles forming an arc with invaginate ends (21)

Two conspicuous accessory bundles in the petiole (22)

Four conspicuous accessory bundles in the 0 petiole (23)

Camptodromous-brochidodromous-

pinnate-like venation (24)

Camptodromous-eucamptodromouspinnate-like venation (25)

Primary vein with branched linear orientation (26) orientation (27)

Primary vein with curved orientation (28) 1 Randomly reticulated tertiary veins (29)

Transversally branched tertiary veins (30) 0

Orthogonal areoles (31)

Irregularly shaped areoles (32)

Aeroles lacking (33)

$\begin{array}{lllllllllllllllll}0 & 0 & 0 & 1 & 1 & 1 & 1 & 0 & 1 & 0 & 0 & 1 & 0 & 1 & 1 & 0 \\ 0 & 1 & 1 & 1 & 0 & 1 & 1 & 1 & 1 & 1 & 1 & 0 & 1 & 1 & 1 & 1 \\ 1 & 0 & 0 & 0 & 1 & 0 & 0 & 0 & 0 & 0 & 0 & 1 & 0 & 0 & 0 & 0 \\ 0 & 1 & 1 & 1 & 1 & 1 & 1 & 1 & 0 & 0 & 0 & 0 & 1 & 1 & 1 & 0 \\ 0 & 0 & 0 & 0 & 0 & 0 & 0 & 0 & 1 & 0 & 1 & 0 & 0 & 0 & 0 & 0 \\ 1 & 0 & 0 & 0 & 0 & 0 & 0 & 0 & 0 & 1 & 0 & 1 & 0 & 0 & 0 & 1 \\ 1 & 1 & 1 & 1 & 1 & 1 & 1 & 1 & 1 & 1 & 0 & 0 & 1 & 1 & 0 & 1 \\ 0 & 0 & 0 & 0 & 0 & 0 & 0 & 0 & 0 & 0 & 1 & 1 & 0 & 0 & 1 & 0 \\ 1 & 0 & 1 & 0 & 0 & 0 & 0 & 0 & 0 & 1 & 0 & 0 & 0 & 1 & 0 & 0 \\ 0 & 1 & 0 & 1 & 1 & 1 & 1 & 1 & 1 & 0 & 1 & 0 & 1 & 0 & 1 & 1 \\ 0 & 0 & 0 & 0 & 0 & 0 & 0 & 0 & 0 & 0 & 0 & 1 & 0 & 0 & 0 & 0\end{array}$


Table 2 continued

\begin{tabular}{|c|c|c|c|c|c|c|c|c|c|c|c|c|c|c|c|c|}
\hline Analyzed characteristics & $\mathrm{BaA}$ & $\mathrm{BaAR}$ & $\mathrm{BaC}$ & $\mathrm{BaG}$ & $\mathrm{BaL}$ & $\mathrm{BaM}$ & $\mathrm{BaP}$ & ByB & $\mathrm{ByCO}$ & ByCR & ByLA & $\mathrm{ByV}$ & HA & HB & $\mathrm{HC}$ & HT \\
\hline Areoles arranged in an oriented pattern (34) & 0 & 0 & 1 & 0 & 0 & 0 & 0 & 0 & 0 & 0 & 0 & 0 & 0 & 1 & 0 & 0 \\
\hline Randomly arranged areoles (35) & 1 & 1 & 0 & 1 & 1 & 1 & 1 & 1 & 1 & 1 & 1 & 0 & 1 & 0 & 1 & 1 \\
\hline Well-developed areoles (36) & 0 & 0 & 1 & 0 & 0 & 0 & 0 & 0 & 0 & 1 & 0 & 0 & 0 & 1 & 0 & 0 \\
\hline $\begin{array}{l}\text { Incompletely closed anastomose areoles } \\
\text { (37) }\end{array}$ & 0 & 1 & 0 & 0 & 0 & 0 & 0 & 0 & 1 & 0 & 0 & 0 & 0 & 0 & 1 & 0 \\
\hline Imperfectly developed areoles (38) & 1 & 0 & 0 & 1 & 1 & 1 & 1 & 1 & 0 & 0 & 1 & 0 & 1 & 0 & 0 & 1 \\
\hline
\end{tabular}

BaA Banisteriopsis anisandra, BaAR B. argyrophylla, BaC B. campestris, BaG B. gardneriana, BaL B. laevifolia, BaM B. malifolia, BaP B. pubipetala, ByB Byrsonima basiloba, ByCO B. coccolobifolia, ByCR B. crassifolia, ByLA B. lancifolia, ByV B. verbascifolia, HA Heteropterys anoptera, HB H. byrsonimifolia, HC H. campestris, HT H. tomentosa

invaginate ends was found in Byrsonima verbascifolia (Fig. 6) and B. crassifolia.

Accessory vascular bundles are observed in all species of Banisteriopsis (Figs. 1-3). They are absent in Byrsonima lancifolia (Fig. 5), Heteropterys anoptera, and H. tomentosa (Fig. 8). Variations in the number of accessory bundles are observed. Two accessory bundles are found in Banisteriopsis anisandra (Fig. 1), B. argyrophylla, B. campestris (Fig. 2), Byrsonima basiloba (Fig. 4), and B. crassifolia, and four in Banisteriopsis gardneriana (Fig. 3), B. laevifolia, B. malifolia, B. pubipetala, Byrsonima coccolobifolia, B. verbascifolia (Fig. 6), Heteropterys byrsonimifolia (Fig. 7), and H. campestris.

The presence of sclereids scattered among the cortical parenchyma is common in Byrsonima (Figs. 4-6).

Leaf blades have thickened cuticle in 14 species (Figs. 10-12), except in Heteropterys campestris and H. tomentosa. Cuticular flanges are observed in all species that have thickened cuticle except for Banisteriopsis argyrophylla and B. pubipetala.

Leaf blades (Figs. 9-14) have a single-layered epidermis on the abaxial side of the leaf in all species. On the adaxial side of the leaf, the epidermis is single-layered in Banisteriopsis campestris (Fig. 10), B. argyrophylla, B. malifolia, B. pubipetala, Bysonima basiloba (Fig. 12), Heteropterys anoptera (Fig. 14), H. byrsonimifolia (Fig. 13), and H. campestris. A noncontinuous bilayered epidermis is found in Banisteriopsis anisandra (Fig. 9), B. gardneriana, $B$. laevifolia, Byrsonima coccolobifolia (Fig. 11), B. crassifolia, B. lancifolia, B. verbascifolia, and Heteropterys tomentosa.

Stomata are paracytic (Fig. 15). In cross-section, subsidiary cells that are large in relation to the guard cells are observed. Cuticular ledges are poorly developed in Banisteriopsis and Heteropterys species (Figs. 16 and 17), while in Byrsonima species, the cuticular ledges are well developed in the guard cells (Figs. 18 and 19).
Three types of branched unicellular nonglandular trichomes are observed: T type (Fig. 20), Y type (Fig. 21), and $\mathrm{V}$ type (Fig. 22). The T type is absent only in Banisteriopsis pubipetala, Byrsonima coccolobifolia, Heteropterys anoptera, and $H$. byrsonimifolia. The $\mathrm{Y}$ type is found in Banisteriopsis argyrophylla, B. campestris, B. laevifolia, B. malifolia, Byrsonima basiloba, and B. crassifolia. The $\mathrm{V}$ type is observed only in Byrsonima basiloba. Trichomes are found on the abaxial side, and there are many of them in Banisteriopsis species, except B. campestris, and in Byrsonima basiloba. In Banisteriopsis campestris, the number of such structures is visibly lower. In Byrsonima crassifolia, B. lancifolia, B. verbascifolia, Heteropterys campestris, and H. tomentosa, the trichomes are observed on both sides, being higher in quantity in $B$. verbascifolia.

Mesophyll is dorsiventral in Banisteriopsis anisandra (Fig. 9), B. argyrophylla, B. gardneriana, B. laevifolia, B. pubipetala, Byrsonima basiloba (Fig. 12), Heteropterys byrsonimifolia (Fig. 13), H. campestris, and H. tomentosa. In Banisteriopsis campestris (Fig. 10), B. malifolia, Byrsonima coccolobifolia (Fig. 11), B. crassifolia, B. lancifolia, B. verbascifolia, and Heteropterys anoptera (Fig. 14), it is isobilateral.

The midrib (Figs. 26-31) is prominent and made up of collateral bundles arranged to form a single arc in all Banisteriopsis species (Figs. 26 and 27) and Heteropterys (Figs. 30 and 31). In Byrsonima, the midrib is prominent and made up of collateral bundles arranged in two arcs (Figs. 28 and 29), one curved towards the adaxial side and the other one towards the abaxial side, the latter one being smaller in most cases. In Banisteriopsis anisandra (Fig. 26) and B. gardneriana, the midrib shows a flat adaxial side. Near the vascular bundles, fibers are observed in Banisteriopsis (Fig. 26), Byrsonima (Figs. 28 and 29), and Heteropterys (Fig. 30), but not in B. argyrophylla (Fig. 27), B. laevifolia, and H. campestris (Fig. 31). 
Figs. 1-8 Diagrammatic schemas of the petiole crosssection of Malpighiaceae species. Fig. 1 Banisteriopsis anisandra. Fig. 2 Banisteriopsis campestris. Fig. 3

Banisteriopsis gardneriana.

Fig. 4 Byrsonima basiloba.

Fig. 5 Byrsonima lancifolia.

Fig. 6 Byrsonima verbascifolia.

Fig. 7 Heteropterys

byrsonimifolia. Fig. 8

Heteropterys tomentosa. Arrow Accessory bundles, dot-filled areas phloem, striped areas xylem, dark areas fibers. Scale $=400 \mu \mathrm{m}$
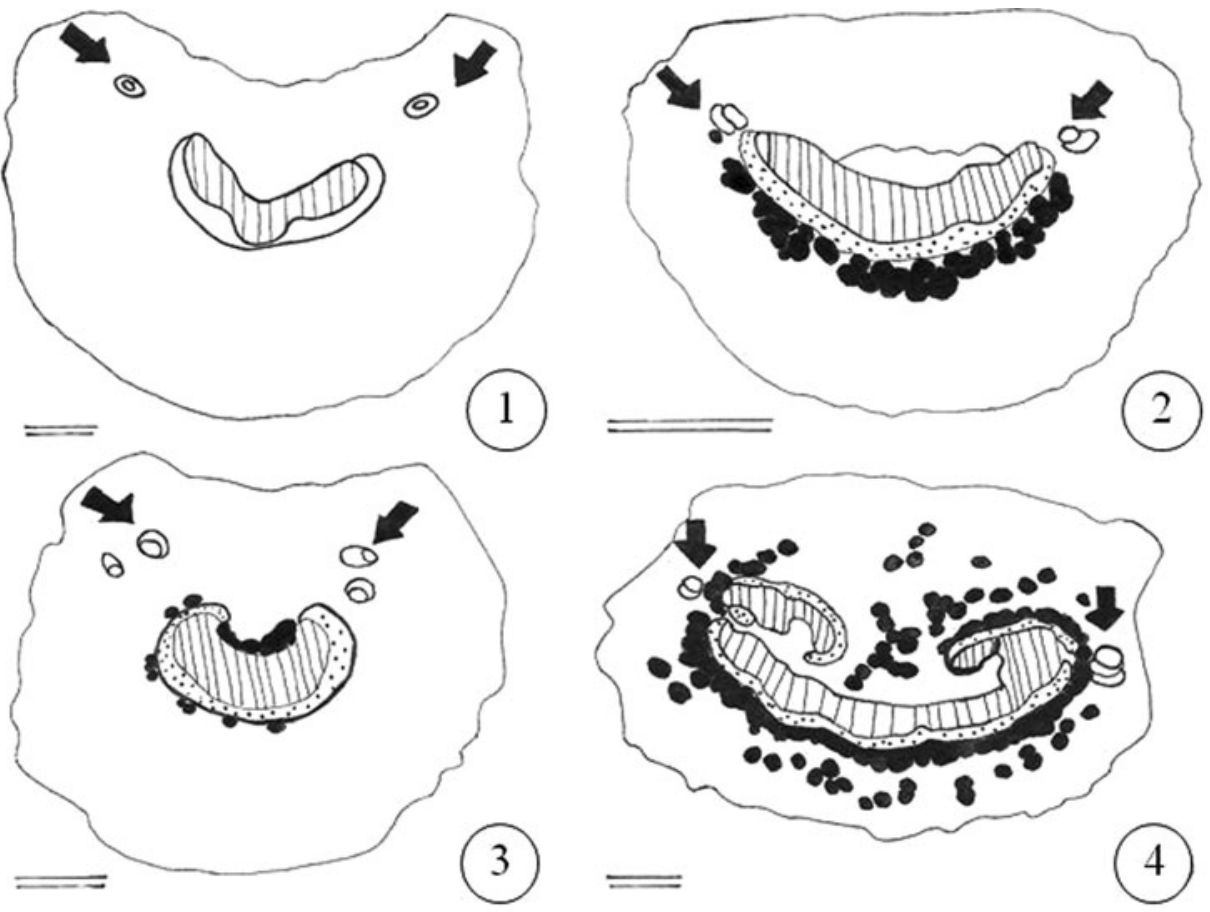

3
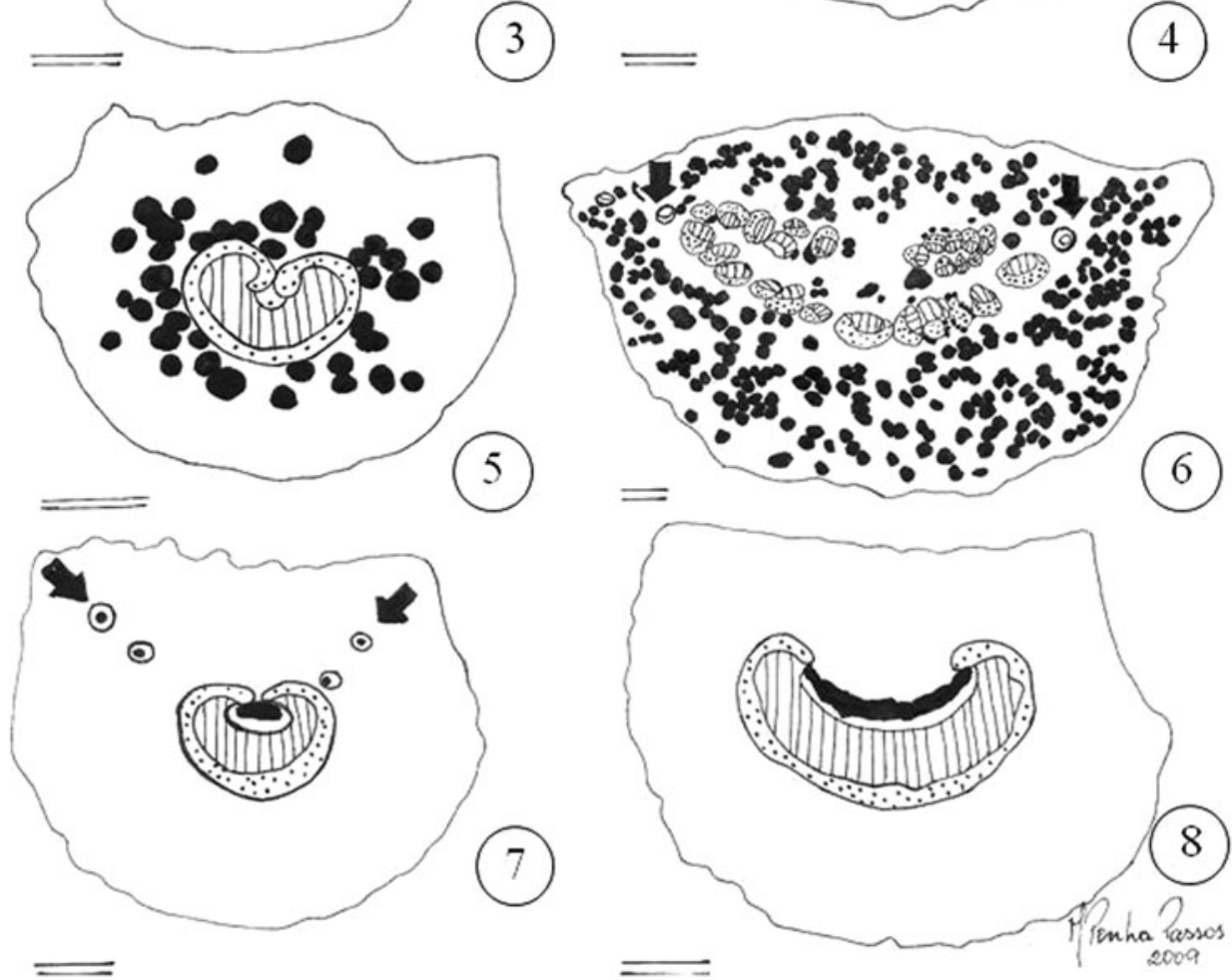

Phloem is found in the medullary region of the midrib in all Byrsonima species (Fig. 28), except in B. coccolobifolia (Fig. 29).

Druses and prismatic crystals occur in all Banisteriopsis and Byrsonima species, both in the mesophyll (Figs. 11 and 12) and the midrib, except in Banisteriopsis pubipetala where they are absent.
Sclerified sheath extensions are observed in largerdiameter vascular bundles in Byrsonima basiloba (Fig. 23), Heteropterys anoptera, and $H$. byrsonimifolia. In Banisteriopsis argyrophylla, B. campestris (Fig. 24), B. laevifolia, B. malifolia, Byrsonima coccolobifolia, B. crassifolia, B. lancifolia, B. verbascifolia, and Heteropterys tomentosa, they are parenchymatic. 
Figs. 9-14 Leaf blade crosssections of Malpighiaceae species. Fig. 9 Banisteriopsis anisandra. Fig. 10

Banisteriopsis campestris.

Fig. 11 Byrsonima

coccolobifolia. Fig. 12

Byrsonima basiloba. Fig. 13

Heteropterys byrsonimifolia.

Fig. 14 Heteropterys anoptera.

$C$ Cuticle, $D$ druses, $P P$ palisade parenchyma, and $S P$ spongy parenchyma, arrow bilayered epidermis. Scale Fig. 9, 10, 13, $\mathbf{1 4}=50 \mu \mathrm{m}$; Fig. 11 and $12=70 \mu \mathrm{m}$

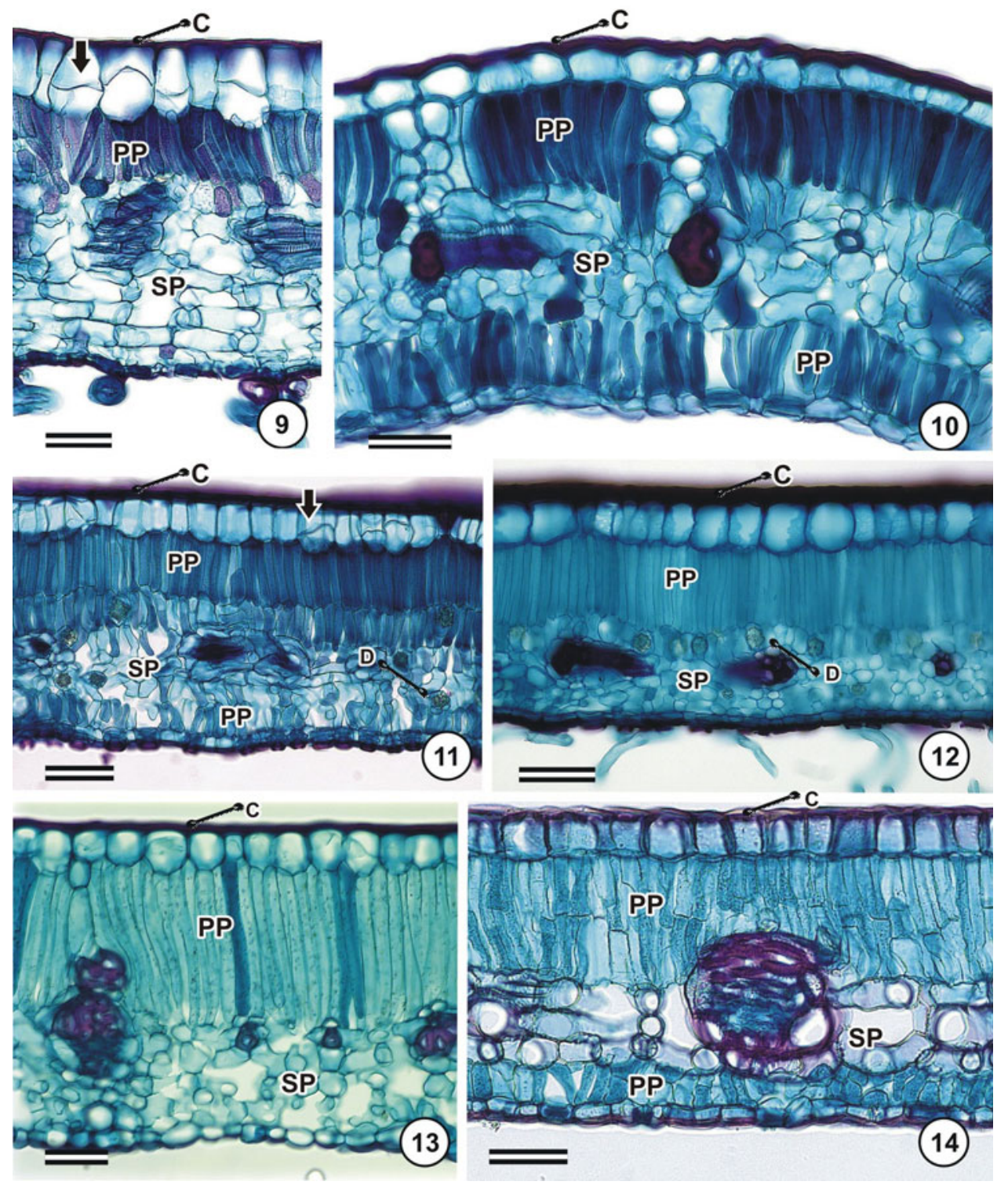

Glands on the lower leaf blade (Fig. 25) are only observed in Banisteriopsis, and only in five out of the seven analyzed species. Such structures are located at three different places: at the distal portion of the petiole (B. anisandra, B. gardneriana, B. laevifolia, and B. malifolia), on the lower abaxial side of the leaf blade (B. campestris), and on the third part of the leaf blade near the midrib (B. laevifolia). Anatomically, these structures are made up of a secretory palisade epidermis and a secretory subepidermic parenchyma (Fig. 25). Vascular endings of xylem and phloem converge to the subepidermic parenchyma (Fig. 25).

A camptodromous-brochidodromous pinnate venation pattern (Figs. 32-40) occurs in all species except
Banisteriopsis anisandra, B. laevifolia, and Byrsonima verbascifolia, where a camptodromous-eucamptodromous pattern is found (not documented). The primary vein shows a straight pattern, except in Banisteriopsis anisandra, Byrsonima crassifolia, B. verbascifolia, Heteropterys anoptera, $H$. byrsonimifolia, $H$. campestris, and $H$. tomentosa where it is curved, and in Byrsonima lancifolia where it is nonbranched and linear. The tertiary veins are randomly reticulate in Banisteriopsis, Byrsonima basiloba (Fig. 35), B. coccolobifolia (Fig. 36), and B. crassifolia (Fig. 37), while in Byrsonima lancifolia (Fig. 38), B. verbascifolia, and $H$. campestris they are transversally branched. Terminal veins are branched in all species, except Byrsonima verbascifolia, where they are simple. Areoles in 
Figs. 15-25 Diaphanized leaf blade (15). Leaf blade cross sections (16-21) of

Malpighiaceae species. Fig. 15 Byrsonima crassifolia: paracytic-like stomata. Fig. 16 Banisteriopsis pubipetala.

Fig. 17 Banisteriopsis laevifolia. Fig. 18 Byrsonima coccolobifolia. Fig. 19 and 22 Byrsonima basiloba. Fig. 20

T-shaped nonglandular trichome in Byrsonima crassifolia. Fig. 21 Y-shaped nonglandular trichome in Banisteriopsis argyrophylla.

Figs. 22 and 23 Byrsonima basiloba. Fig. 22 Detail of V-shaped nonglandular trichome in Fig. 22. Figs. 24 and 25 Banisteriopsis campestris, detail of the glandular structure on the lower leaf blade shown in Fig. 25 (arrow). $S$ Stomata, $S E$ sheath extension, $P E$ palisade epidermis, $P$ phloem, and $X$ xylem. Scale: Fig. 15, 20 , 22-24 = $50 \mu \mathrm{m}$; Fig. 16$\mathbf{1 9}=30 \mu \mathrm{m}$; Fig. $21=70 \mu \mathrm{m}$; Fig. $24=150 \mu \mathrm{m}$
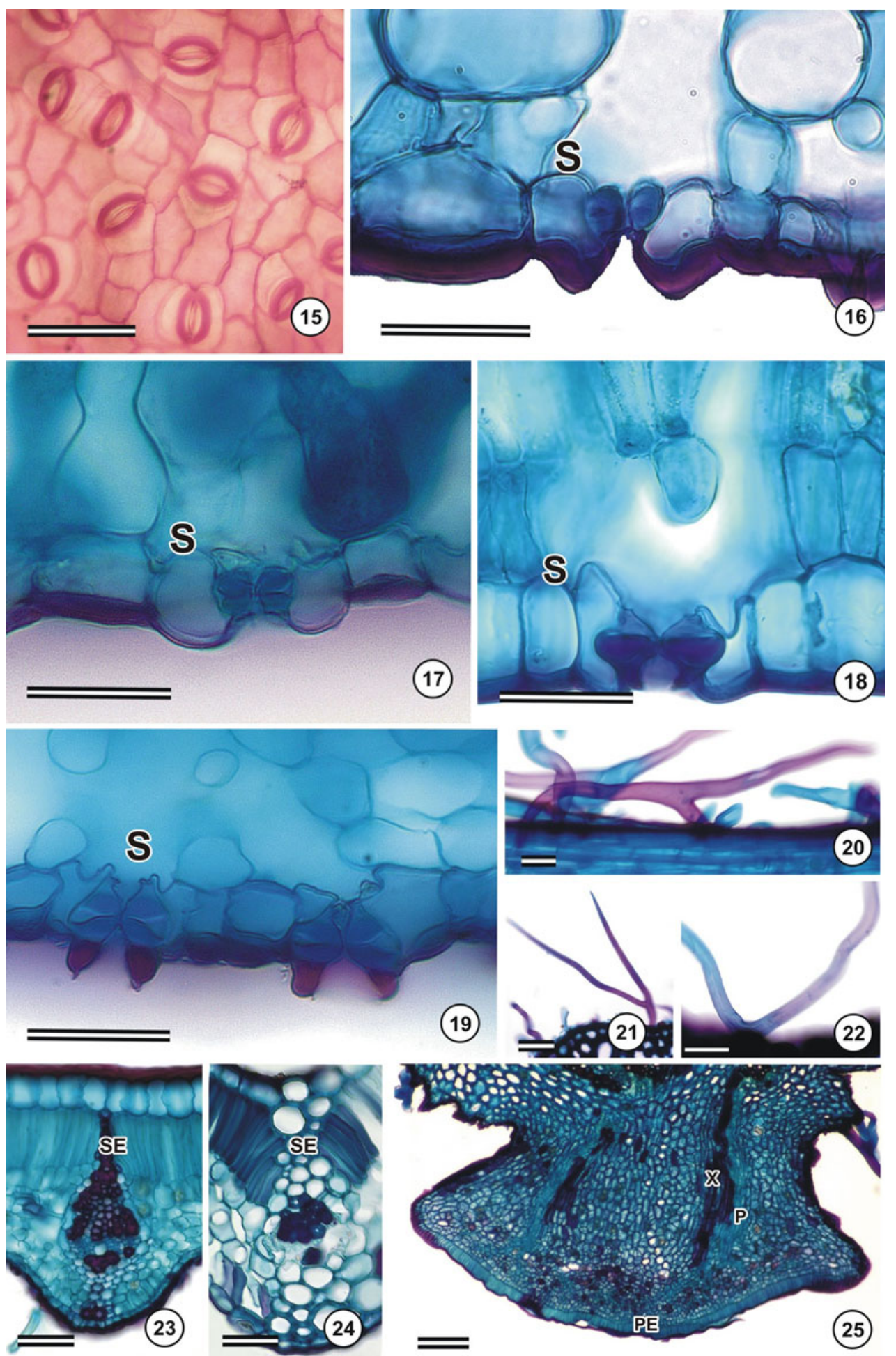

Banisteriopsis argyrophylla (Fig. 32), Byrsonima coccolobifolia (Fig. 36), and H. campestris show incompletely closed anastomoses; in Banisteriopsis campestris (Fig. 33), Byrsonima crassifolia (Fig. 37), and $H$. byrsonimifolia (Fig. 40), they are well developed; in Banisteriopsis species (Fig. 34), they are branched; and in Byrsonima basiloba (Fig. 35), B. lancifolia (Fig. 38), B. verbascifolia, H. anoptera (Fig. 39), and H. tomentosa, they are imperfect. The areole shape is irregular (Figs. 32, 34-36, 38, and 39), except for Banisteriopsis campestris (Fig. 33), B. anisandra, Byrsonima crassifolia (Fig. 37), and H. byrsonimifolia (Fig. 40), where they show an orthogonal pattern. 
Figs. 26-31 Schemas of leaf blade cross-sections in

Malpighiaceae species. Fig. 26 Banisteriopsis anisandra with prominent midrib and flat adaxial side surface. Fig. 27 Banisteriopsis argyrophylla with prominent midrib and absent fibers. Fig. 28 Byrsonima basiloba with prominent midrib and phloem within the midrib.

Fig. 29 Bysonima

coccolobifolia with prominent midrib and no phloem within the midrib. Fig. 30

Heteropterys anoptera with prominent midrib and bundles arranged in open arc. Fig. 31 Heteropterys campestris with prominent midrib and bundles arranged in open arc. Dot-filled areas $\mathrm{Phloem}$, striped areas xylem, dark areas fibers. Scale $=300 \mu \mathrm{m}$
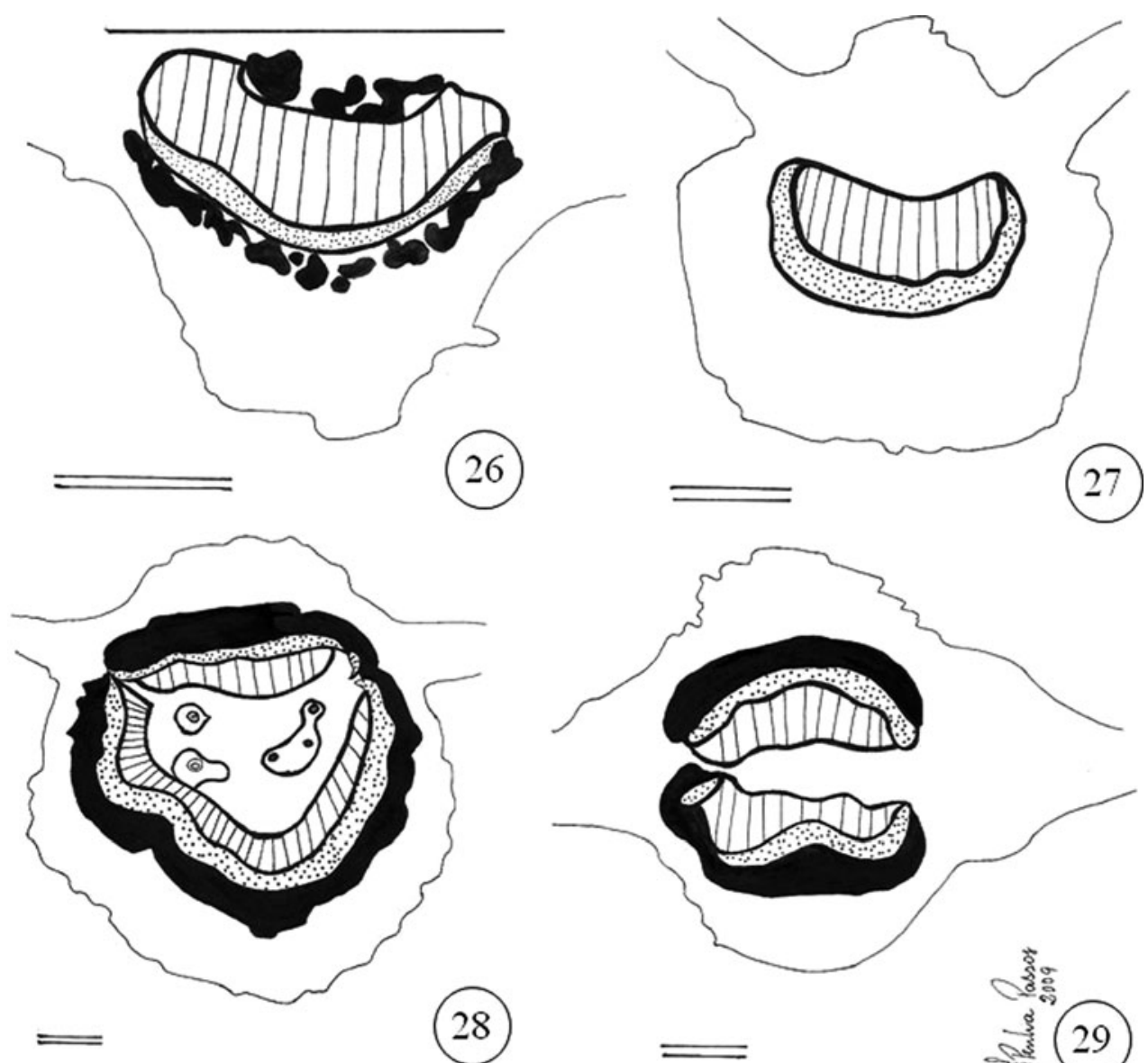

28

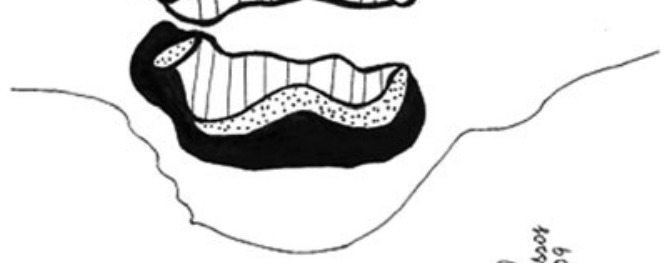

\%
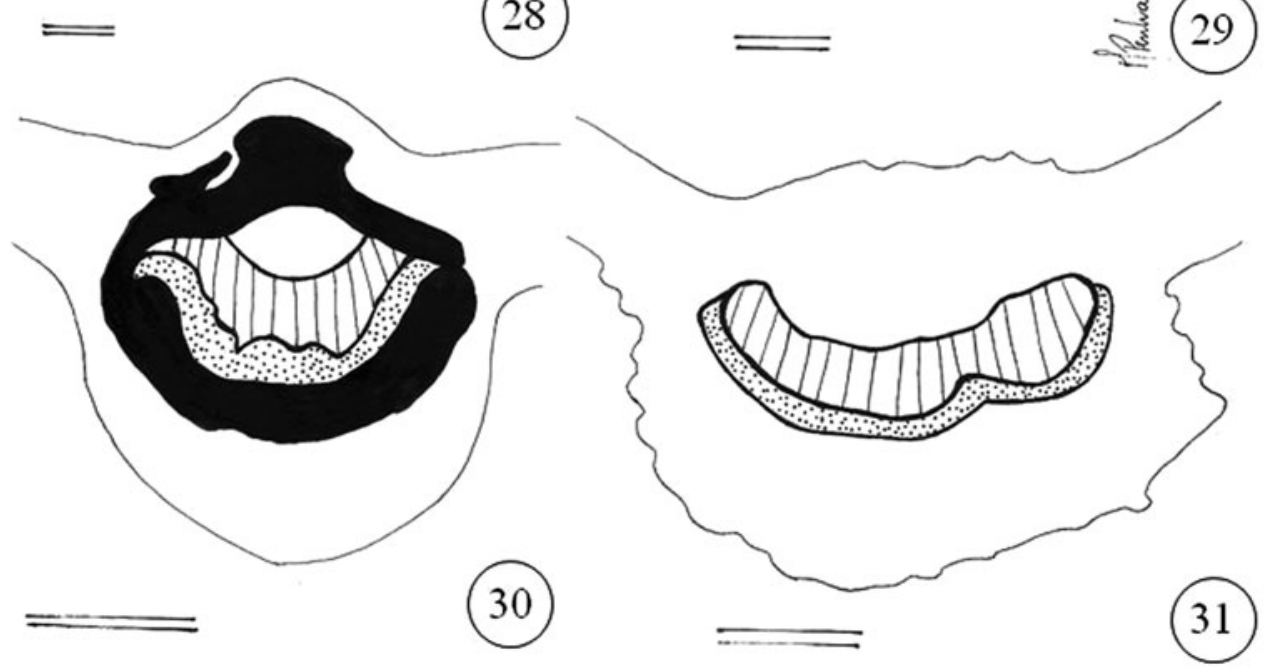

All species show looped venation endings on the leaf border, which are enclosed by secondary, tertiary, and quaternary arcs.

\section{Similarity analysis}

The similarity analysis (Fig. 41) was performed based on presence/absence (Table 2) to distinguish three groups: one includes Byrsonima verbascifolia and B. crassifolia; the second Byrsonima coccolobifolia, Byrsonima lancifolia, and Byrsonima basiloba; and the third, which groups all Banisteriopsis and Heteropterys species. The presence of phloem in the midrib rib and stomata with developed cuticular ledges in the guard cells is the characteristic that incorporated Byrsonima species in the first group. Regarding the second group, the major similarity among the species is the presence of a petiolar vascular bundle arranged in the shape of an arc, which invaginates at the ends and includes areoles of irregular shape in the blade. The third group, formed by Banisteriopsis and Heteropterys species, 
Figs. 32-40 Diagrammatic schemas of the venation patterns in diaphanized leaf blades of Malpighiaceae species. Fig. 32 Banisteriopsis argyrophylla: areole with incompletely closed anastomose and irregular shape.

Fig. 33 Banisteriopsis

campestris: well-developed orthogonal areoles. Fig. 34 Banisteriopsis gardneriana: branched areole with irregular shape. Fig. 35 Byrsonima basiloba: randomly reticulated tertiary veins with imperfect areoles and irregular shape.

Fig. 36 Byrsonima coccolobifolia: randomly reticulated tertiary veins, areole with incompletely closed anastomose and irregular shape. Fig. 37 Byrsonima crassifolia: randomly reticulated tertiary veins, well-developed orthogonal areoles. Fig. 38 Byrsonima lancifolia: transversally branched tertiary veins, with imperfect areoles and irregular shape. Fig. 39 Heteropterys anoptera: imperfect areoles with irregular shape. Fig. 40. Heteropterys byrsonimifolia: well-developed orthogonal areoles.

Scale $=400 \mu \mathrm{m}$
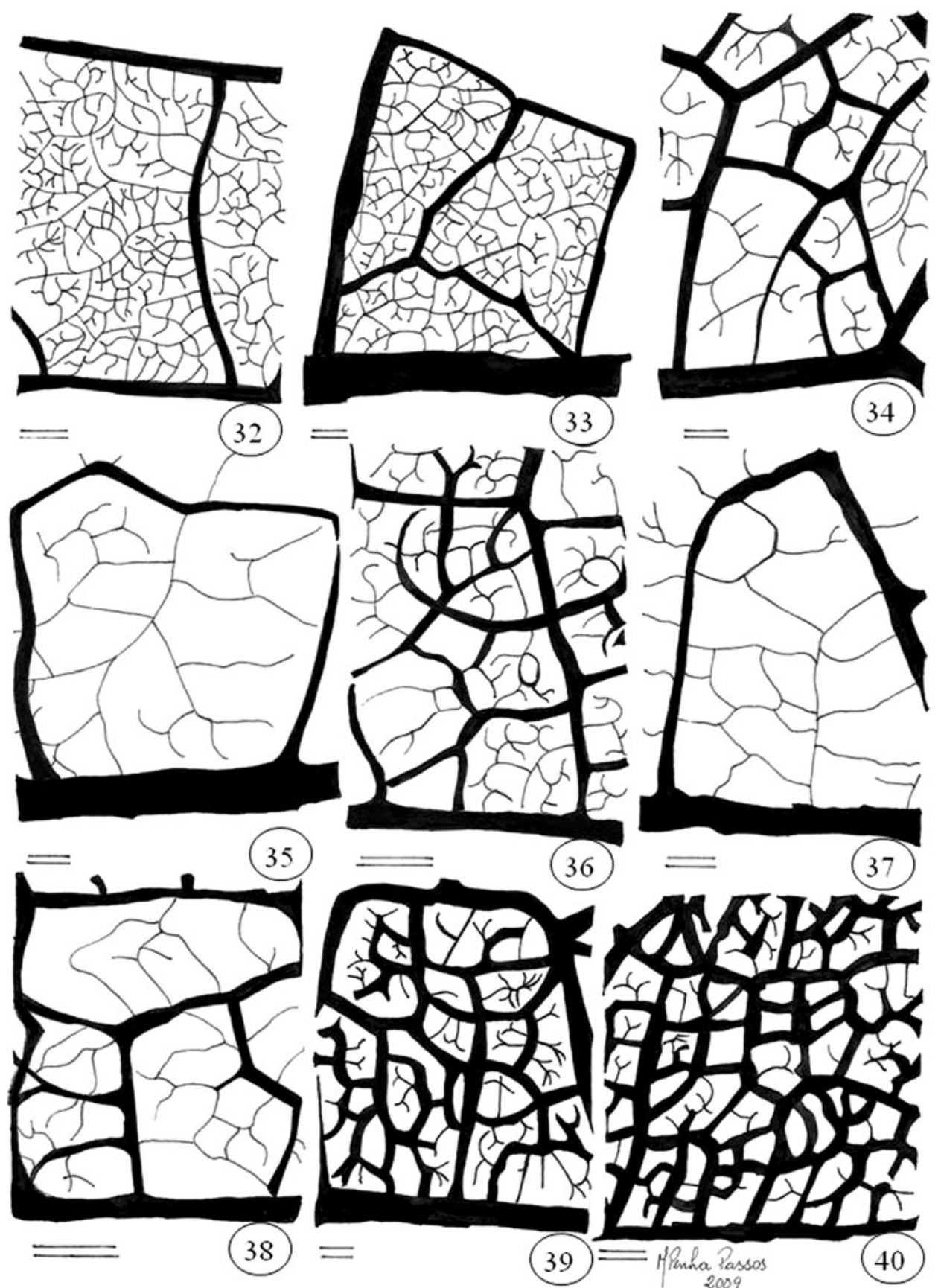

35
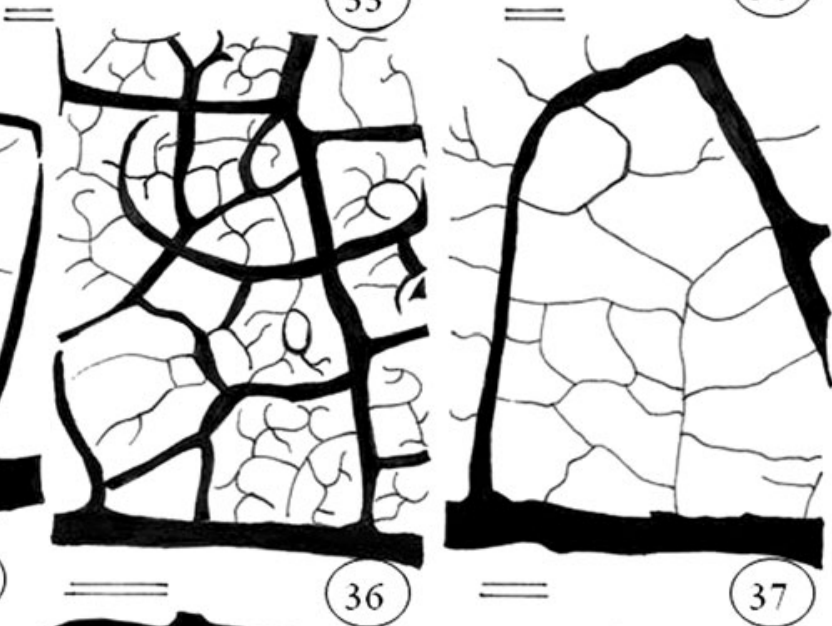

(37)

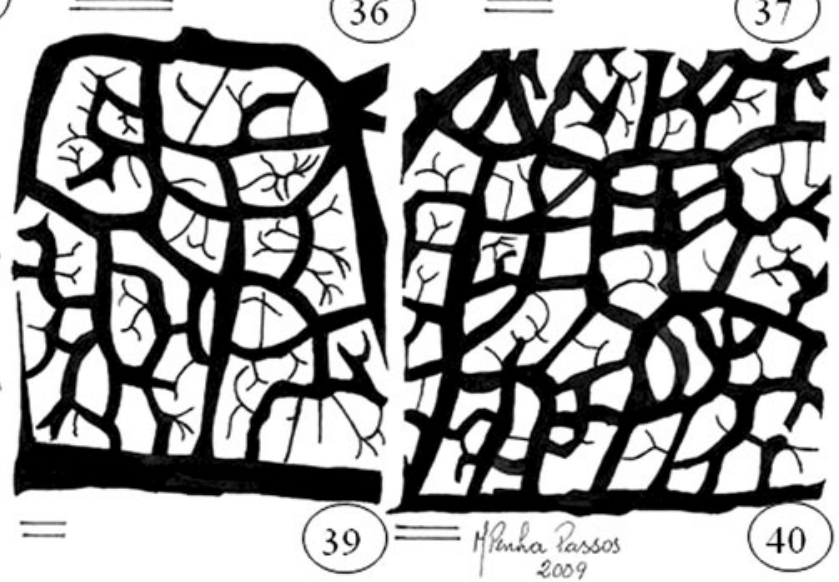

contains well-developed subsidiary cells in relation to the guard cells and has a single vascular bundle arranged in an arc in the midrib.

In the PCA (Fig. 42), it was possible to distinguish two groups of characteristics, one which defines Byrsonima and the other Banisteriopsis. However, Heteropterys could not be distinguished (Fig. 42). The following characteristics are found exclusively in the Byrsonima genus: guard cells forming a ledge only on the outer side (3), V-shaped nonglandular trichomes (9), vascular bundles arranged in a closed arc with phloem in the midrib rib (15), vascular bundles arranged in a closed arc without phloem in the medullary region of the midrib (16), petiolar vascular system consisting of free bundles forming an arc with invaginate ends (21), primary vein with nonbranched linear orientation (27), primary vein with curved orientation (28), transversally branched tertiary veins (30), and no aerolation (33). The following were characteristic of the Banisteriopsis genus: one pair of leaf glands (5), glands present at the petiole base (6), 
Fig. 41 Grouping analysis of Banisteriopsis, Byrsonima, and Heteropterys species. BaA

Banisteriopsis anisandra. BaAR

B. argyrophylla, $\mathrm{BaC}$

B. campestris, $B a G$

B. gardneriana, BaL

B. laevifolia BaM B. malifolia,

BaP B. pubipetala, $B y B$

Byrsonima basiloba, ByCR

B. crassifolia, $B y C O$

B. coccolobifolia, ByLA

B. lancifolia, ByV B.

verbascifolia, HA Heteropterys anoptera, $H B H$. byrsonimifolia, HC H. campestris, HT

H. tomentosa

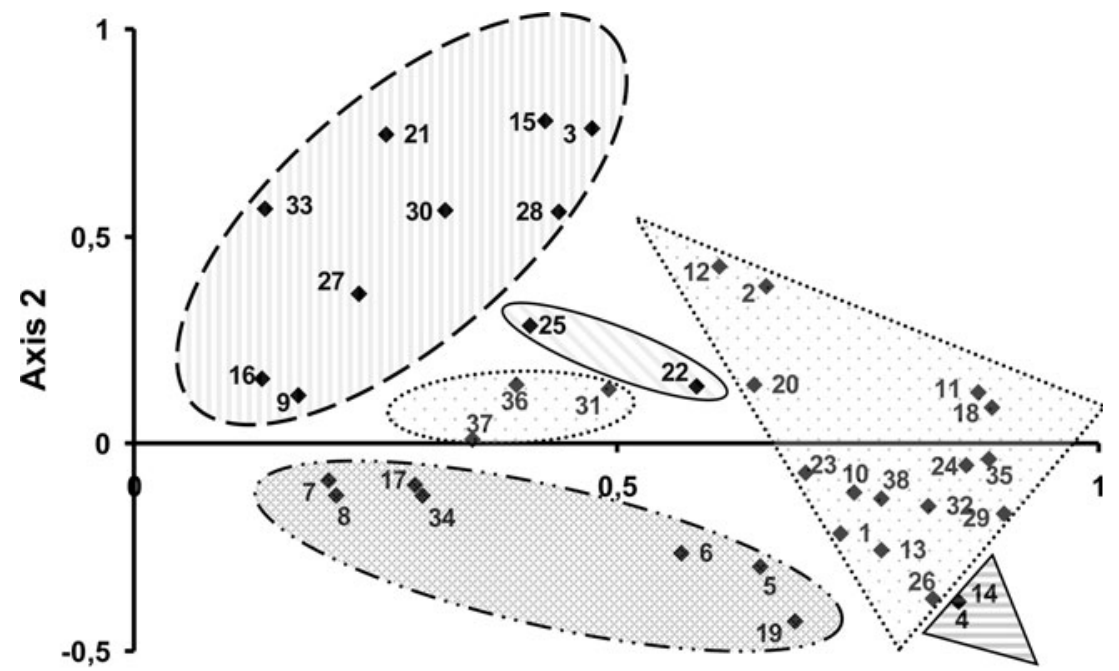

Axis 1

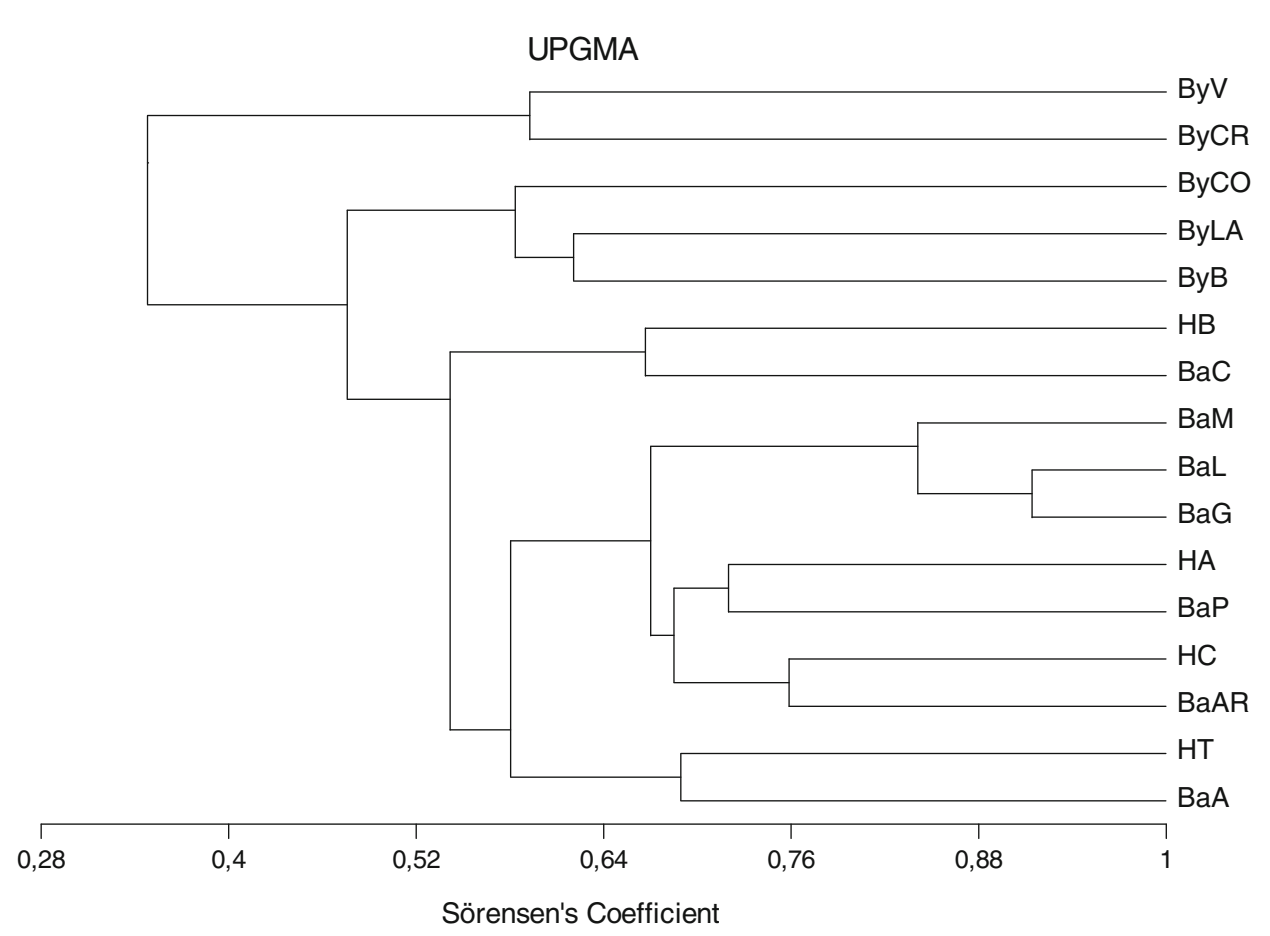

Fig. 42 Biplot principal component analysis (PCA) of Banisteriopsis, Byrsonima, and Heteropterys species....indicates characters for Banisteriopsis species; [प] indicates characters for Byrsonima species; :......... indicates characters for Banisteriopsis, Byrsonima, and Heteropterys species; indicates characters for Banisteriopsis and Byrsonima species; and $\square$ indicates characters for Banisteriopsis and Heteropterys species. The triangles indicate symplesiomorphies and ellipses synapomorphies glands present in the lower part of the leaf (7), glands present in the middle part of the leaf (8), petiole with concave-convex shape on cross-section (17), petiolar vascular system arranged as a curved arc (19), and areoles arranged in an oriented pattern (34).

Both analyses pointed to Byrsonima as the most isolated group if compared to Banisteriopsis and Heteropterys. In a cluster analysis, Byrsonima formed two groups with its entire species placed before Banisteriopsis and Heteropterys species, which were grouped into clusters (Fig. 42).
In the PCA analysis (Fig. 42), Byrsonima showed nine exclusive traits and Banisteriopsis seven. The group of characters found near or at the end of axis 1 indicated by both triangles occurs in all three genera; however two of these characters (represented by the smaller triangle) are only present in Banisteriopsis and Heteropterys. Between the two major clusters (i.e., the two biggest ellipses, which have characters found exclusively in Banisteriopsis or Byrsonima), there are two smaller ellipses grouping characters for some species of the three genera or some species of Banisteriopsis and Byrsonima. 


\section{Identification key}

1. Presence of a pair of glands on the leaf.

2. One pair of glands on the lower abaxial side .............Banisteriopsis campestris

2'. One pair of glands near the third part of the midrib ....Banisteriopsis laevifolia

2". One pair of glands on the distal portion of the petiole...

3. Absence of Y shape trichomes......

Banisteriopsis anisandra

3'. Presence of $Y$ shape trichomes

4. Isobifacial leaves

Banisteriopsis malifolia

4". Dorsiventral leaves.

Banisteriopsis gardneriana

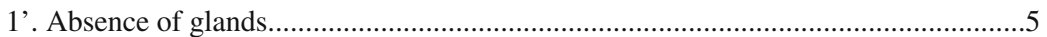

5. Presence of phloem in the midrib rib .6

6. Dorsiventral leaves. Byrsonima basiloba

6'. Isobifacial leaves

7. Petiolar vascular system consists of a single bundle arranged

in the form of an invaginated arc Byrsonima lancifolia

7'. Petiolar vascular constituted by free bundles forming an arc with invaginate ends................................................................ 8. Two accessory bundles in the petiole...................................................... Byrsonima crassifolia 8'. Four conspicuous accessory bundles in the petiole. Byrsonima verbascifolia

5'. Absence of phloem in the midrib rib.. 9

9. Presence of trichomes.

10. Absence of accessory bundles in the petiole. Heteropterys tomentosa 10'. Presence of two accessory bundles in the petiole. Banisteriopsis argyrophylla

10". Presence of four accessory bundles in the petiole

H. campestris

9'. Absence of trichomes.

11. Isobifacial leaves 12

12. Absence of accessory bundles in the petiole. H. anoptera

12'. Presence of four accessory bundles in the petiole Byrsonima coccolobifolia

11'. Dorsiventral leaves. 13

13. Petiolar vascular system arranged in the form of a curved arc...........Banisteriopsis pubipetala

13. Petiolar vascular system arranged in the form of an arc invaginated at ends. H. byrsonimifolia 


\section{Discussion}

It was possible to identify meaningful characters for the three genera studied. These characters may be applied to the taxonomy of Malpighiaceae. Anatomy has been a useful tool for taxonomy and has been successfully used since the 19th century (Solereder 1908; Metcalfe and Chalk 1979). The importance of the anatomy as an additional tool for taxonomy is evident when fragmented material needs to be identified, when reproductive structures are not available, or even to indicate evolutionary trends and phylogenetic relationships among taxa (Metcalfe and Chalk 1979). Anatomy studies in the Malpighiaceae family may be very important once the fruit morphology is the main character used in taxonomy and phylogeny. It has been emphasized that molecular data combined with morphological characters may enhance the understanding of the evolution of Malpighiaceae (Cameron et al. 2001; Davis et al. 2001).

Regarding the vascular bundle in the petiole, the form of an arc with invaginated ends was considered the most common type among the studied species, observed in nine species among three genera. A pattern with a high number of free bundles forming an invaginated arc was restricted to the genus Byrsonima. The form of a curved arc was exclusive and predominant in Banisteriopsis. The petiole vascularization is a promising character and must be considered in future taxonomic reviews, especially at the genus level. Although references regarding the use of such a character in the Malpighiaceae taxonomy were not found, few studies have described this character for few species. In Peixotoa hispidula (Ferreira 1981), Heteropterys angustifolia (Arambarri et al. 2006), and Mascagnia pubiflora (Guimaraes et al. 1985), the petiole vascular bundle forms an arc, similar to the most common type of petiole vascularization among the species studied. The importance of the petiole vascularization for taxonomy has been reported for other groups, for instance in Melastomataceae, where the character helped distinguish five genera, or in the genus Chamaecrista (Leguminosae/Caesalpinioideae), where this characteristic was considered to be diagnostic for the studied species (Reis et al. 2004; Francino 2006).

The presence and number of accessory bundles were considered meaningful diagnostic characters for the analyzed species. Most of the species showed four or two accessory bundles. The absence of this structure was not very common. This character is useful when distinguishing species, being similar to what was described for the genus Erythroxylum of Erythroxylaceae (Bieras and Sajo 2004).

Three types of nonglandular trichomes $(\mathrm{V}, \mathrm{Y}$, and $\mathrm{T}$ types) were observed in 12 of the 16 analyzed species. Such types of trichomes are characteristic of Malpighiaceae and are considered to be diagnostic for this family (Metcalfe and Chalk 1979; Gates 1982; Judd et al. 2007).
Byrsonima basiloba was the only species that showed the three types of trichomes; for this reason, they are considered to be diagnostically meaningful. Although the T type has been observed in individuals of the three analyzed genera, it was the only one found in Heteropterys. Nonglandular types of trichomes have been used in taxonomic reviews, as for Banisteriopsis where the $\mathrm{Y}$ or $\mathrm{T}$, or $\mathrm{Y}$ and $\mathrm{T}$ types were found in 67 species. This characteristic was considered important and was used in the identification key presented for this genus (Gates 1982). It is important to emphasize that the lack of nonglandular trichomes on expanded leaves must be considered with care, as it is very common for these trichomes to be deciduous, as recorded for Byrsonima coccolobifolia (Beiguelman 1962a).

Paracytic type stomata were seen in all species, while a bilayered epidermis was found only in 7 of the 16 studied species (Banisteriopsis anisandra, B. gardneriana, B. laevifolia, Byrsonima crassifolia, B. lancifolia, B. verbascifolia, and Heteropterys tomentosa). These results confirm literature records, increasing the number of studied species and genera of the Brazilian flora (Beiguelman 1962a; Metcalfe and Chalk 1979; Attala 1997). Mascagnia pubiflora has an anomocytic stomata type (Guimaraes et al. 1985), which may be additional evidence of the polyphyletic hiraeoid clade that was demonstrated by molecular phylogenetic analysis (Cameron et al. 2001).

The mesophyll types found in many studied species are in accordance with the literature for individuals of the Malpighiaceae family (Beiguelman 1962b; Attala 1997; Pereira 2002). However, it is important to note that even though a dorsiventral mesophyll was recorded for Byrsonima coccolobifolia (Beiguelman 1962b), it is believed that such an interpretation is misleading. As the substomatal chambers in this species are large, and there are many stomata, the palisade parenchyma facing the abaxial side is constantly interrupted, which could make it difficult to recognize the isobifacial mesophyll.

The presence of phloem in the midrib was restricted to the Byrsonima genus, which makes this an important diagnostic character at the genus level.

One pair of glands, found in different places, was observed in five of the seven species of Banisteriopsis. Glands were absent in the other genera analyzed. Metcalfe and Chalk (1979), Anderson (1990), and Judd et al. (2007) have reported the presence of glands on vegetative organs in most genera and species of Malpighiaceae in both the New and Old World. They are commonly found on the petiole, on the leaf abaxial side, and on bracts and bracteoles. These structures are morphologically and anatomically similar to the analyzed species. Structures that resemble such glands were reported in Banisteriopsis anisandra and B. gardneriana (Attala 2004) and were characterized as extrafloral nectaries (Anderson 1990; Attala 
2004). These glands are quite similar in their anatomical structure and occur in a position analogous to the position of elaiophores found on the sepals of most neotropical Malpighiaceae (Anderson 1990). Since herbarium material was used in the present work, tests to verify the presence of sugars in the glandular secretion of the Banisteriopsis were not performed.

The venation pattern for most species was brochidodromous. Only Banisteriopsis anisandra, B. laevifolia, and Byrsonima verbascifolia showed eucamptodromous type. According to Judd et al. (2007), one of the characteristics for most species of the Malpighiaceae family is the brochidodromous-like venation, which was confirmed by our observations and was related to Peixotoa hispidula (Ferreira 1981), further indicating the eucamptodromous pattern as a distinctive characteristic.

The morphology of the winged fruit (Gates 1982; Amorim 2002) allows differentiation between Heteropterys (dorsal wing with thickened abaxial border) and Banisteriopsis (dorsal wing with thickened adaxial border). However, the results of leaf anatomy show that at the species level, the clades are well defined for the species analyzed. It is so reliable that it was possible to build an identification key for those species.

The analysis of similarity showed that for the Malpighiaceae species found in the FLONA of Paraopeba, the genus Byrsonima is well delimited, since the analyzed species formed a consistent group and were isolated from Banisteriopsis and Heteropterys. These results are corroborated by the molecular phylogenetic analysis in which Byrsonima is allocated in the diverse clade of Heteropterys and Banisteriopsis (Cameron et al. 2001; Davis et al. 2001).

Intrafamilial classification and intergeneric relationships have not been agreed upon (Anderson 1978; Davis et al. 2001; Cameron et al. 2001). For the time being, according to molecular phylogeny analysis the only monophyletic group is the banisterioid (Cameron et al. 2001; Davis et al. 2001). The anatomical multivariate analyses showed that Byrsonima was derived before Banisteriopsis and Heteropterys, in keeping with the molecular phylogenetic analyses (Cameron et al. 2001; Davis et al. 2001).

In the PCA, single characters for Byrsonima are accumulated in the positive direction for axis 2 , while the ones for Banisteriopsis are found on the negative side. These differences may be considered as another argument for Banisteriopsis being one of the several most derived genera of the banisterioid clade, which concurs with what Cameron et al. (2001) had earlier hypothesized while studying the molecular systematics of Malpighiaceae. The group of characters found near or at the end of axis 1 outlined by the two triangles (Fig. 42) suggests symplesiomorphies for the three genera; however two of these characters included in the smaller triangle (Fig. 42) are only present in
Banisteriopsis and Heteropterys. Byrsonima seems to have derived first from the main branch of Malpighiaceae while Banisteriopsis and Heteropterys are thought to have derived later. These results corroborate the molecular phylogeny of Malpighiaceae (Cameron et al. 2001; Davis et al. 2001). Apparently, two smaller ellipses found in the PCA correspond to parallel apomorphies that occurred in some species of the three genera or in some species of Banisteriopsis and Byrsonima.

Anatomically, the analyzed 16 species showed differences that indicate the importance of anatomy for taxonomic evaluation. It was possible to indicate promising characters for future taxonomic and phylogenetic studies on the Malpighiaceae family, regarding not only the delimitation of Banisteriopsis, Byrsonima, and Heteropterys but also the other genera and species.

Acknowledgments This report is part of the MSc. dissertation of J.S.A. The authors thank the CNPq (Conselho Nacional de Desenvolvimento Científico e Tecnológico), FAPEMIG (Fundação de Amparo a Pesquisa do Estado de Minas Gerais) for its financial support, and João Augusto Alves Meira Neto for the assistance on the principal component analysis (PCA).

\section{References}

Amorim AM (2002) Five new species of Heteropterys (Malpighiaceae) from Central and South America. Brittonia 54:217-232

Anderson WR (1978) Byrsonimoideae, a new subfamily of the Malpighiaceae. Leandra 7:5-18 (1977)

Anderson WR (1979) Floral conservatism in neotropical Malpighiaceae. Biotropica 11:219-223

Anderson WR (1990) The origin of the Malpighiaceae: the evidence from morphology. Mem NY Bot Gard 64:210-224

Anderson C (2001) The identity of two water-dispersed species of Heteropterys (Malpighiaceae): H. leona and H. platyptera. Contr Univ Michigan Herb 23:35-47

Arambarri AM, Freire SE, Colares MN, Bayon ND, Novoa MC, Monti C, Stenglein SA (2006) Leaf anatomy of medicinal shrubs and trees from gallery forests of the Paranaense Province (Argentina). Part 1. Bol Soc Argent Bot 41:233-268

Attala NC (1997) Fitografia e morfoanatomia de Banisteriopsis anisandra e $B$ gardneriana (Malpighiaceae): estudo comparativo. Dissertação de Mestrado, Instituto de Ciências Biológicas, Universidade de Brasília

Attala NC (2004) Morfoanatomia da lâmina foliar, estrutura e histoquímica das glândulas foliares e calicinais em espécies de Malpighiaceae de cerrado. PhD Thesis, Instituto de Biociências, Universidade Estadual de São Paulo "Júlio de Mesquita Filho," Botucatu, SP

Beiguelman B (1962a) Considerações sobre a morfologia dos estomas de Annona coriaceae Mart., Byrsonima coccolobifolia Kunth., Erythroxylum suberosum St. Hil. e Ouratea spectabilis (Mart.). Engl Rev Bras Biol 22:115-124

Beiguelman B (1962b) Contribuição para o estudo anatômico das plantas do cerrado, II: anatomia da folha e do caule de Byrsonima coccolobifolia Kunth. Rev Biol 3:111-123

Bieras AC, Sajo MG (2004) Anatomia foliar de Erythroxylum P. Browne (Erythroxylaceae) do Cerrado do estado de São Paulo, Brasil. Act Bot Brasil 18:601-612 
Borges HBN, Shepherd GJ (2005) Flora e estrutura do estrado lenhoso numa comunidade de Cerrado em Santo Antônio do Leverger, MT, Brasil. Rev Bras Bot 28:61-74

Cameron KM, Chase MW, Anderson WR, Hills HG (2001) Molecular systematics of Malpighiaceae: evidence from plastid $R B C L$ and MATK sequences. Am J Bot 88:1847-1862

Davis CC, Anderson WR, Donoghue MJ (2001) Phylogeny of Malpighiaceae: evidence from chloroplast $n d h F$ and trnl-F nucleotide sequences. Am J Bot 88:1830-1846

Dickison WC (2000) Integrative plant anatomy. Academic, New York Ferreira GL (1981) Anatomia foliar de Peixotoa hispidula Juss. (Malpighiaceae). Arq Jard Bot Rio de Janeiro 25:45-53 (1982)

Fonsêca LC, Proença CEB, Gonçalves EG (2007) Descrição do padrão de venação foliar em Spathicarpa Hook. (Araceae). Act Bot Brasil 21:213-221

Francino DMT (2006) Anatomia foliar de espécies de Chamaecrista Moench. (Leguminosae/Caesalpinioideae) ocorrentes em campo rupestre. Tese de Mestrado, Universidade Federal de Viçosa, Viçosa

Gates B (1982) Banisteriopsis, Diplopterys (Malpighiaceae). Fl Neotropica Monogr 30:1-237

Gavilanes ML, Ferreira MB (1974-1976) Malpighiaceae do Distrito Federal, III: GENERO Pterandra Juss. Oreades 5(7-9):17-29

Gomes SMA, Silva EAM, Lombardi JA, Azevedo AA, Vale FHA (2005) Anatomia foliar como subsídio à taxonomia da subfamília Hippocrateoideae (Celastraceae). Act Bot Brasil 19:945-961

Guimaraes DJ, Magalhaes HG, Araujo RR, Monteiro Neto HC, de Oliveira BAD (1985) Estudio anatomico de plantas toxicas brasileiras, Mascagnia pubiflora (Juss.) Griseb., Malpighiaceae. Bol Mus bot Kuhlmann 8(1):11-18

Howard RA (1979) The petiole. In: Metcalfe CR, Chalk L (eds) Anatomy of the dicotyledons: systematic anatomy of the leaf and stem, vol I, 2nd ed. Oxford Claredon, Oxford pp 88-96

Judd WS, Campbell CS, Kellog EA, Stevens PF, Donoghue MJ (2007) Plant systematics: a phylogenetic approach, 3rd ed. Sinauer Associates, Sunderland

Kraus JE, Arduin M (1997) Manual básico de métodos em morfologia vegetal. Editora da Universidade Federal Rural do Rio de Janeiro, Rio de Janeiro

Makino-Watanabe H, Melhem T, Barth OM (1993) Morfologia dos grãos de pólen de espécies de Banisteriopsis C. B. Robinson ex Small (Malpighiaceae). Rev Bras Bot 16:47-67

Mamede MCH (1981) O gênero Byrsonima Rich. Ex A. L. Juss. (Malpighiaceae) na Serra do Cipó, Minas Gerais, Brasil. PhD Thesis, Instituto de Biociências, Universidade de São Paulo, São Paulo
Mamede MCH (1993) Anatomia dos órgãos vegetativos de Camarea (Malpighiaceae). Act Bot Brasil 7:3-19

Mendonça RC, Felfili JM, Walter BHT, Silva Jr.MC da S, Rezende AV, Vilgueiras T de S, Nogueira PE, Fagg CW (2008) Flora vascular do bioma Cerrado. In: Sano SM, Almeida SP de, Ribeiro JF (eds) Cerrado ecologia e flora, Cap 15, vol II. Embrapa Informação Tecnológica, Brasília

Metcalfe CR, Chalk L (1950) Anatomy of the dicotyledons, vol II. Oxford Claredon, Oxford

Metcalfe CR, Chalk L (1979) Anatomy of the dicotyledons: systematic anatomy of the leaf and stem, vol I, 2 ed. Oxford Claredon, Oxford

Mueller-Dombois D, Ellenberg H (1974) Aims and methods of vegetation ecology. Wiley, New York

Neri AV, Campos EP, Duarte TG, Meira Neto JAA, Silva AF, Valente GE (2005) Regeneração de espécies nativas lenhosas sob plantio de Eucalyptus em área de cerrado na Floresta Nacional de Paraopeba, MG, Brasil. Act Bot Brasil 19:369-376

Pereira KBD (2002) Micropropagação e estudo morfo-anatômico do endocarpo, semente e plântula de Byrsonima basiloba Juss. Dissertação de Mestrado, Instituto de Ciências Biológicas, Universidade de Brasília, Brasília

Ratter JA, Ribeiro JF, Bridgewater S (1997) The Brazilian cerrado vegetation and threats to its biodiversity. Ann Bot 80:223-230

Reis C, Proença SL, Sajo MG (2004) Vascularização foliar e anatomia do pecíolo de Melastomataceae do cerrado do Estado de São Paulo, Brasil. Act Bot Brasil 18:987-999

Rio MCS, Kinoshita LS, Castro MM (2005) Anatomia foliar como subsídio para a taxonomia de espécies de Forsteronia G. Mey. (Apocynaceae) dos cerrados paulistas. Rev Bras Bot 28:713-726

Rohlf FJ (1988) Numerical taxonomy and multivariate analysis system. Freeman, New York

Saporetti AW Jr, Meira-Neto JAA, Almado RP (2003) Fitossociologia de cerrado sensu stricto no município de Abaeté-MG. Rev Árv 27:413-419

Shobe WR, Lersten NR (1967) A technique for clearing and staining gymnosperm leaves. Bot Gaz 127(2):150-152

Smith FH, Smith EC (1942) Anatomy of the inferior ovary of Darbya. Am J Bot 29:464-471

Sokal RR, Rohlf FJ (1995) Biometry, 3 ed. Freeman, New York

Solereder H (1908) Systematic anatomy of the dicotyledons, vol I. Claredon, Oxford

Theobald WL, Krahulik JL, Rollins RC (1979) Trichome description and classification. In: Metcalfe CR, Chalk L (eds) Anatomy of the dicotyledons: systematic anatomy of the leaf, stem, vol I, 2 ed. Oxford Claredon, Oxford pp 40-53 